\title{
Turkish Adaptation of the Berkeley Parenting Self-Efficacy Scale Revised (BPSE-R)
}

\begin{tabular}{ccc}
\hline $\begin{array}{c}\text { Article Type } \\
\text { Research }\end{array}$ & $\begin{array}{c}\text { Received Date } \\
10.08 .2020\end{array}$ & $\begin{array}{c}\text { Accepted Date } \\
14.12 .2020\end{array}$ \\
\hline Tülin Güler Yıldız $^{*}$ & Figen Şahin $^{* *}$ \\
Gelengül Haktanır $^{* * *}$ & Susan Holloway $^{* * * *}$
\end{tabular}

\begin{abstract}
The purpose of this study is to adapt the Berkeley Parenting Self-Efficacy Scale Revised (BPSER) to Turkish. The scale is composed of two subscales, parental strategies and child outcomes, and includes 18 items. In the process of adapting the scale and examining its reliability and validity, 354 mothers of preschool children were selected through convenience sampling. After translation-and back translation procedures, the BPSE-R was evaluated by field experts, and the scale items were found to be consistent. Confirmatory factor analysis showed that the scale has a two-factor structure similar to the original scale. The fit indices obtained for this two-factor structure were found to be at a good level. The total score Cronbach's alpha internal consistency coefficient was calculated as 0.91 , and the test-retest reliability coefficient was calculated as 0.67 . Findings demonstrated that the Turkish version of the BPSE-R has adequate psychometric characteristics and can be used in determining the self-efficacy of parents in Turkey with preschool-aged children. The short duration in which the BPSE-R can be applied and its high reliability make it convenient for use in research.
\end{abstract}

Keywords: Early childhood, parenting, self-efficacy, parenting self-efficacy, Berkeley Parenting Self-Efficacy Scale Revised, BPSE-R.

\footnotetext{
* Corresponding Author: Prof. Dr. Hacettepe University Faculty of Education Department of Early Childhood Education, Ankara, Turkey. E-mail: tguler@ hacettepe.edu.tr, https://orcid.org/ 0000-0002-9518-0336

${ }^{* *}$ Dr. Gazi University Faculty of Education Department of Early Childhood Education, Ankara, Turkey. E-mail: figensahin@ gazi.edu.tr, https://orcid.org/0000- 0001-5614-6883

*** Prof. Dr. Ankara University Faculty of Educational Sciences Department of Early Childhood Education, Ankara, Turkey. E-mail: gelengulhaktanir@gmail.com, https://orcid.org/0000-0002-0783-592X

${ }^{* * * * *}$ Prof. Dr. University of California Berkeley Graduate School of Education, California, USA.

E-mail: susanholloway@berkeley.edu, https://orcid.org/0000-0001-9527-794X
} 


\title{
Yenilenmiş Berkeley Ebeveyn Öz Yeterlik Ölçeğinin (BPSE-R) Türkçe'ye Uyarlama Çalışması
}

\begin{tabular}{ccc}
\hline Makale Türü & Başvuru Tarihi & Kabul Tarihi \\
Araştırma & 10.08 .2020 & 14.12 .2020 \\
\hline
\end{tabular}

\author{
Tülin Güler Yıldız \\ Gelengül Haktanır ***
}

\author{
Figen Şahin**
}

Susan Holloway ${ }^{* * * *}$

\begin{abstract}
Öz
Bu çalışmanın amacı Berkeley Ebeveyn Öz Yeterlik Ölçeğinin yenilenmiş versiyonunu (BPSER)Türkçe'ye uyarlamaktır. BPSE-R'da toplam 18 madde bulunmakta ve Ebeveynliğe Özgü Stratejiler ve Çocuğa Kazandırılabilecekler olmak üzere iki alt ölçekten oluşmaktadır. Ölçeği Türkçe'ye uyarlama ve geçerli ve güvenilir olup olmadığını inceleme sürecinde kolay örnekleme yöntemi ile ulaşılan ve okul öncesi dönemde çocukları olan 354 anne çalışmaya katılmıştır. BPSE-R çeviri ve tersine çeviri işlemlerinden sonra alan uzmanları tarafından değerlendirilmiş ve ölçek maddelerinin uygun olduğu belirlenmiştir. Doğrulayıcı faktör analizi ölçeğin orjinalindeki gibi iki faktörlü yapıya sahip olduğunu göstermiştir ve bu yapıya ilişkin uyum indeksleri iyi düzeyde bulunmuştur. Ölçeğin toplam puan Cronbach alfa iç tutarlılık katsayısı 0.91, test-tekrar test kararlılık katsayısı ise 0.67 olarak hesaplanmıştır. Bulgular BPSE-R'ın Türkçe versiyonunun yeterli psikometrik özelliklere sahip olduğunu ve Türkiye'de okul öncesi dönemde çocuğu olan anne babaların ebeveynlik öz yeterliğinin belirlenmesinde bir ölçme aracı olarak kullanılabileceğini göstermiştir. BPSE-R ölçeğinin uygulamasının kısa sürmesi ve güvenirliğinin yüksek olması araştırmalarda kullanılmasında kolaylık sağlayacaktır.
\end{abstract}

Anahtar Sözcükler: Erken çocukluk, ebeveynlik, öz yeterlik, ebeveyn öz yeterliği, Yenilenmiş Berkeley Ebeveyn Öz Yeterlik Ölçeği, BPSE-R.

\footnotetext{
* Sorumlu Yazar: Prof. Dr. Hacettepe Üniversitesi Temel Eğitim Bölümü Okul Öncesi Eğitimi Anabilim Dalı, Ankara, Türkiye. E-posta: tguler@hacettepe.edu.tr, https://orcid.org/ 0000-0002-9518-0336

${ }^{* *}$ Dr. Gazi Üniversitesi Temel Eğitim Bölümü Okul Öncesi Eğitimi Anabilim Dalı, Ankara, Türkiye. E-posta: figensahin@gazi.edu.tr, https://orcid.org/0000- 0001-5614-6883

${ }^{* * *}$ Prof. Dr. Ankara Üniversitesi Temel Eğitim Bölümü Okul Öncesi Eğitimi Anabilim Dalı, Ankara, Türkiye. E-posta: gelengulhaktanir@gmail.com, https://orcid.org/0000-0002-0783-592X

${ }^{* * * * *}$ Prof. Dr. University of California Berkeley Graduate School of Education, California, USA.

E-posta: susanholloway@ berkeley.edu, https://orcid.org/0000-0001-9527-794X
} 


\section{Introduction}

Self-efficacy is a concept that attracts much attention in the disciplines of psychology and education and is believed to have an important effect on the behaviors of an individual. Self-efficacy, one of the factors declared to influence behavior in Social Cognitive Theory, is defined as the belief of individuals about their capacity to control the events in their lives (Bandura, 1977; Bandura, 1982). According to Bandura (1982, p. 122), self-efficacy affects individuals" "thought patterns, actions, and emotional arousal". Therefore, self-efficacy is the self-belief of an individual with regards to coping with certain situations, making an effort to succeed in an activity and the capacity to sustain this effort despite all obstacles (de Montigny \& Lacharité, 2005; Senemoglu, 2007).

Individuals' beliefs about their self-efficacy are related to a specific area, therefore an individual is not expected to have high levels of efficacy in every area. On the other hand, having efficacy in areas concerning one's purposes and tasks may encourage actions in line with these purposes. Beliefs about efficacy in a specific area such as parenthood are related to the thoughts, actions, and emotions of the individual pertaining to that area (Bandura, 2002). Therefore, self-efficacy beliefs about parenthood can be considered among the strong determinants of parents' actions (Holloway, et al., 2019).

Parenting self-efficacy is described as the perceptions of a mother or father about how adequate they are in their parenting roles, or their perception of being able to affect their children's behaviors and development positively (Coleman \& Karraker, 2000). Judgments of parents regarding their abilities or skills of fulfilling the parenting tasks they consider important are related to their selfefficacy. When parents feel they can make a positive change in the lives of their children, it can be stated that they have a high level of self-efficacy (Coleman \& Karraker, 1998; Holloway, 2010).

Considering that parents' beliefs about successfully undertaking child-raising activities have a substantial effect on children (Schneewind, 1995), it may be argued that individuals who feel confident in raising their children do better in difficult situations than individuals that do not trust their parenting skills. Indeed, parents' self-efficacy has been associated with psychological well-being and positive parenting behavior (Coleman \& Karraker, 2003; Holloway, 2010; Holloway, et al., 2016; Suzuki, Holloway, Yamamoto, \& Mindnich, 2009). As parents with low self-efficacy levels focus on their own inadequacies, they consider any problem about child rearing as a threat instead of a positive difficulty. These parents may experience a feeling of failure when they face a tough situation in parenthood (Holloway, 2010). This emotional situation may prevent them from treating their children in a proper and consistent way (Holloway et al., 2019; Uyanık Balat, 2015).

Since individual' feelings of competence affect their thoughts and behaviors, it can be stated that parents' seeing themselves as having competent parenting skills affects both family life and children's development and education (Bandura, 1982; Schneewind, 1995). For this reason, there is a need for measurement tools to be used in determining the self-efficacy of parents and for research in this area. Bandura (2002) claims that self-efficacy can be assessed by measurement tools designed for specific domains, such as parenthood, instead of being assessed by domain-general tools. For the individual to evaluate her/himself as confident in general may not translate to evaluating her/himself as adequate in terms of parenting skills. Therefore, Bandura emphasizes that performance-specific evaluations or measurements in a certain area, such as parenting, may have a higher degree of accuracy (Bandura, 2002; Bandura, 2006).

Parenting Self Efficacy Scales adapted for parents with children of various age groups exist in Turkey. These include the Parental Efficacy Scale (Kaya, 2011) evaluating how parents help their children in primary school, and the Perceived Parental Self Efficacy Scale (PPSE), intended to measure the efficacy levels of parents with children in middle and high school (Demir \& Gunduz, 2014). The Parental Self-Efficacy Instrument for Children with Disabilities adapted to Turkish by Cavkaytar, Aksoy, and Ardıç (2014), on the other hand, was developed for identifying the parenting self-efficacy of parents with special needs children.

Measurement tools intended to identify the self-efficacy of parents with preschool children are limited in number. Seçer, Çeliköz, and Yasa (2007) adapted the Parenting Sense of Competence Scale 
developed by Gibaud-Wallston and Wandersman (1978) and named it the Attitude Scale for Parenting-Father Form. This scale includes dimensions of fathers' perceptions of efficacy regarding fatherhood duties ( 7 items), their interest in fatherhood duties ( 2 items) and the satisfaction they derive from fatherhood duties (7 items). Similarly, the Parenting Self-Efficacy Scale adapted by Kotil (2010) aims to determine the self-efficacy of mothers who have five-year-old children starting preschool. Adapted from the Self-Efficacy for Parenting Tasks Index developed by Coleman and Karraker (2000), this scale was based on the task-specific approach and includes items specific to the performance of mothers with children who are starting school in the dimensions of attention, discipline, care, participation, and health. The Turkish version of the Self-Efficacy for Parenting Task Index-Toddler Scale, adapted by Elibol, Mağden, and Alpar (2007), aims to determine the selfefficacy of parents with children between one and three years of age. Another scale is the Parental Self-Efficacy Scale developed for parents with babies between three and six months. It is used to specify self-efficacy perceptions in the transition to parenthood (K1liçaslan, 2007).

The first version of the Berkeley Parenting Self-Efficacy Scale (BPSE) was also used in studies on self-efficacy among parents in Turkey with preschool-aged children (Uyanık Balat, 2014; Uyanık Balat \& Y1lmaz, 2014; Zembat, Uyanık Balat, Çinko, Şengül, \& Acar, 2008). The scale consists of two dimensions, including 25 items intended to evaluate the extent to which parents feel competent in their behaviors towards their children and in supporting them to acquire certain developmental tasks suitable for their ages. Developed in 2005, the BPSE scale (Holloway, Suzuki, Yamamoto, \& Behrens, 2005) was updated in 2019 and now includes 18 items in total, with some previous items removed and several newly added ones, in two dimensions: parental strategies and child outcomes (Holloway et al., 2019).

Consistent with Bandura's (2006) concept of self-efficacy as the basis of individual's behaviors in a particular area, the BPSE-R was also developed with a domain-specific feature for families with preschool-aged children. The present study aims to adapt the revised version of the Berkeley Parenting Self-Efficacy Scale (BPSE-R) to Turkish. In doing so, the study contributes to the field as there is a limited number of self-efficacy scales for parents with preschool children. Also, the BPSE-R pre-primary and primary forms have been adapted for use in the USA, Japan (Holloway et al., 2019), Korea (Holloway et al., 2016), and China (Wang, 2019), therefore emerging as a reliable scale in different cultures (Hambleton, 2005).

\section{Method}

During the adaptation process of the BPSE-R scale, confirmatory factor analysis (CFA) was first undertaken to confirm the factor structure of the scale. Following this, internal consistency of the scale and test-retest coefficient analyses were conducted to determine its reliability.

\section{Study Group}

The data of the study were obtained from 287 mothers recruited through convenience sampling who have preschool-aged children and voluntarily participated in the study. Demographical variables related to the study group are summarized in Table 1 below. 
Table 1

Distribution of mothers in the study group according to demographic variables

\begin{tabular}{|c|c|c|c|}
\hline \multirow[t]{2}{*}{ Variable } & & \multicolumn{2}{|c|}{ Study Group } \\
\hline & & $\mathbf{N}$ & $\%$ \\
\hline \multirow[t]{4}{*}{ Age } & 30 and below & 89 & 31.0 \\
\hline & $31-40$ & 172 & 59.9 \\
\hline & 41 and above & 16 & 5.6 \\
\hline & Missing data & 10 & 3.5 \\
\hline \multirow[t]{4}{*}{ Educational Background } & High school and below & 139 & 48.5 \\
\hline & Bachelor's degree & 128 & 44.6 \\
\hline & Graduate degree & 12 & 4.1 \\
\hline & Missing data & 8 & 2.8 \\
\hline \multirow[t]{4}{*}{ Monthly Income } & 1500 and below & 24 & 8.4 \\
\hline & $1501-5500$ & 176 & 61.4 \\
\hline & 5501 and above & 36 & 12.5 \\
\hline & Missing data & 51 & 17.8 \\
\hline \multirow[t]{4}{*}{ Number of children } & 1 & 79 & 27.5 \\
\hline & 2 & 167 & 58.2 \\
\hline & 3 and above & 36 & 12.5 \\
\hline & Missing data & 5 & 1.7 \\
\hline \multirow[t]{3}{*}{ Family Unit } & Nuclear family & 206 & 71.8 \\
\hline & Not nuclear family & 51 & 17.7 \\
\hline & Missing data & 30 & 10.5 \\
\hline \multirow[t]{3}{*}{ Child's gender } & Girl & 143 & 49.8 \\
\hline & Boy & 135 & 47.0 \\
\hline & Missing data & 9 & 3.1 \\
\hline
\end{tabular}

Additionally, test-retest reliability was ensured by implementing the scale at a four-week interval with 57 volunteering mothers. Coding was used to ensure confidentiality and to match the data in the two administrations. Of the mothers in the test-retest group, $56.2 \%$ were between the ages of $31-40$, and $10.5 \%$ of them had a high school degree or below.

\section{Instruments}

A demographic information form collating information on parents and children and the Berkeley Parenting Self-Efficacy Scale Revised (BPSE-R) were used in the adaptation study.

\section{Demographic Information Form}

Designed by the researchers, this form contained questions related to age, educational background, monthly income, number of children, child's gender, and the family unit. Forms were completed individually by the mothers participating in the study.

\section{Berkeley Parenting Self-Efficacy Scale Revised (BPSE-R)}

The first version of the Berkeley Parenting Self-Efficacy Scale (BPSE) (Holloway et al., 2005) was originally developed in three separate forms for families with children in the pre-primary age group and the first and second grades of primary school. The BPSE Pre-primary version included 25 items (Holloway et al., 2005). The BPSE Pre-primary version comprises two subscales, namely maternal strategies (10 items) based on a self-evaluation of parenting behaviors, and child outcomes (15 items) based on a self-evaluation of parents about how successfully they support their children as they acquire certain skills. The scale was designed as a 6-point Likert scale $(1=$ not confident at all; 6 $=$ completely confident).

The adaptation of the original BPSE scale (Holloway et al., 2005) to Turkish was conducted by Zembat et al. (2008). The maternal strategies dimension included in the Turkish form consists of two factors regarding the child as an individual and emotional control. The child outcomes subscale, on the other hand, includes the two factors of supporting social skills and supporting individual skills (Zembat et al., 2008). 
More recently, the developers of the original scale revised it and conducted extensive validation work in the United States and Japan (Holloway et. al., 2019). During the revision of the first version of the scale developed in 2005 (Holloway et. al., 2005), a preliminary analysis was performed based on a pool of 29 items, including newly added or deleted items. Ultimately, the revised version of the Pre-primary form demonstrated a two-factor structure with strong validity and test-retest reliability in the US and Japan and consists of 18 items and two sub-scales, namely parental strategies and child outcomes (Holloway et al., 2019). Mirroring the development of the BPSE-R, the initial Turkish version of the revised scale contained the same 29 items as did the English version, and a subsequent adaptation study was conducted with 18 items in line with its original version. An abbreviated version of the items is displayed in Table 2.

\section{Adaptation Process of Berkeley Parenting Self-Efficacy Scale Revised (BPSE-R)}

In line with the criteria recommended in the literature (Hambleton, 2005; Hambleton \& Patsula, 1999) concerning the adaptation of the BPSE-R scale, the developer of the original scale (S. Holloway), was contacted, and permission was obtained to adapt the scale from English to Turkish. In the second stage, the original scale was translated from origin language into the target language separately by two experts in the field of early childhood education who are proficient in both Turkish and English and as well as a linguist. Translations were examined by experts and a single Turkish form was constructed. The Turkish form was then re-translated into English by experts in the field of early childhood education who are proficient in both Turkish and English. Back translations of the scale were reviewed by Holloway and possible cases of the semantic shift were discussed.

In the third stage, the latest version of the Turkish form was revised according to the opinions of experts in the field. During this process, the item "teaching letters" was changed to "teaching concepts" in line with the recommendation of the experts and also because the Ministry of National Education (MoNE) Preschool Education Program (MoNE, 2013) does not include teaching letters to preschool children. In the adaptation process, the Turkish form was given to 10 mothers with children in the preschool age group, and feedback was received regarding whether there were parts that needed editing by discussing with the mothers the topics of scale instructions, clarity, and comprehensibility of the items. The implementation style of the original scale was kept.

\section{Data Analysis}

In the adaptation process, first-level confirmatory factor analysis (CFA) was conducted using LISREL 8.4. The aim was to determine if the resulting scale had the same factor structure as the original one. In the process of developing the model, the normality assumption was tested and it was observed that it did not ensure normality assumption. Therefore, robust maximum likelihood estimation (RMLE) was utilized. Reliability analysis was completed by using the SPSS 20 software package. Cronbach's alpha internal consistency coefficient and Pearson's Product-Moment Correlation Coefficient were calculated.

\section{Results}

In order to identify the factor structure of the scale, CFA was used to examine as the factor loadings $(\lambda)$ of each item and the square of the multiple correlations $\left(\mathrm{R}^{2}\right)$, which determines the strength of the relationship between each item and factor and $t$ values. The results of the analysis are provided in Table 2. According to CFA, the factor loadings related to the "Parental Strategies" dimension ranged between 0.52 and 0.79 , while those related to the "Child Outcomes" dimension varied between 0.48 and 0.78 . 
Table 2

Confirmatory Factor Analysis Results for the Parenting Self-Efficacy Scale

\begin{tabular}{lccc}
\hline Items* & $\boldsymbol{\Lambda}$ & $\mathbf{R}^{\mathbf{2}}$ & $\mathbf{t}$ \\
\hline Parental Strategies & & & \\
A1. Listen to child & 0.78 & 0.61 & 18.84 \\
A2. Understand child's feelings & 0.79 & 0.62 & 17.91 \\
A3. Control emotions in front of child & 0.53 & 0.28 & 9.79 \\
A4. Avoid over-reacting & 0.63 & 0.40 & 12.87 \\
A5. Explain things clearly & 0.79 & 0.62 & 16.43 \\
A6. Praise child & 0.60 & 0.36 & 10.18 \\
A7. Discipline child firmly & 0.52 & 0.27 & 10.34 \\
Child Outcomes & 0.48 & 0.24 & \\
B1. Eat healthy foods & 0.50 & 0.25 & 9.30 \\
B2. Get enough sleep & 0.75 & 0.56 & 9.81 \\
B3. Be polite & 0.62 & 0.38 & 15.79 \\
B4. Behave well without being told & 0.75 & 0.56 & 15.63 \\
B5. Express thoughts clearly & 0.78 & 0.61 & 17.04 \\
B6. Learn concepts & 0.78 & 0.61 & 17.58 \\
B7. Enjoy a picture book & 0.49 & 0.24 & 8.68 \\
B8. Try to do things on own & 0.57 & 0.32 & 11.47 \\
B9. Get along with other children & 0.58 & 0.34 & 10.45 \\
B10. Help other children when they need it & 0.60 & 0.36 & 11.45 \\
B11. Care about other's feelings & &
\end{tabular}

* Abbreviated versions of scale items are presented.

For a two-dimensional model of the BPSE-R, the explanation for the observed variables by each latent variable was examined through t-values (Çokluk, Şekercioğlu \& Büyüköztürk, 2012). The tvalue calculated for the factor loading of the observed variable was found to be higher than the critical t-value (the critical value being 1.96 at the significance level of 0.05 , the critical value being 2.56 at the significance level of 0.01 ) thus showing the factor loading to be statistically meaningful (Çelik \& Y1lmaz, 2013). Each item's t-value was examined via confirmatory factor analysis results, and all items had significant factor loadings $(\mathrm{p}<0.01)$.

Fit indices were used to evaluate the goodness of fit of the observed CFA data to the model. Common fit indices used in the literature are RMSEA, S-RMR, $\chi 2 / \mathrm{df}, \mathrm{CFI}, \mathrm{NFI}$, and NNFI. A $\chi^{2 / \mathrm{df}}$ ratio below five and S-RMR and RMSEA values below 0.08 indicate a good fit between the data and the model (Jöreskog \& Sorbom, 1993; Kline, 2005; Marsh \& Hocevar, 1985). Additionally, CFI, NFI, and NNFI values above 0.95 show an excellent fit while values above 0.90 show a good fit (Kline, 2005; Sümer, 2000). The fit indices of the model are shown in Table 3.

Table 3

Goodness of Fit Indices for the Factor Structure

\begin{tabular}{lcc}
\hline Goodness of fit indices & Acceptable limit & Model in the study \\
\hline$\chi 2 /$ df & $<5$ & $475,67 / 134=3.55$ \\
RMSEA & $<0.08$ & 0.077 \\
S-RMR & $<0.08$ & 0.059 \\
GFI & $>0.90$ & 0.85 \\
CFI & $>0.90$ & 0.96 \\
NFI & $>0.90$ & 0.95 \\
NNFI & $>0.90$ & 0.96 \\
RFI & $>0.90$ & 0.94 \\
\hline
\end{tabular}

As shown in Table 3, most of the fit indices indicate that two dimensional model is a good fit for the data. In short, the BPSE-R is seen to have a two-factor structure for the sample based on confirmatory factor analysis (CFA) results. It was also determined that the items loading on the first factor were included in the parental strategies subscale, while the items loading on the second factor were included in the child outcomes subscale. It can therefore be stated that the factors in the scale 
and the items in the factors fully coincided with the original BPSE-R. A factorial model related to the scale items is presented in Figure 1. The correlation coefficient between factors of the scale was 0.79.

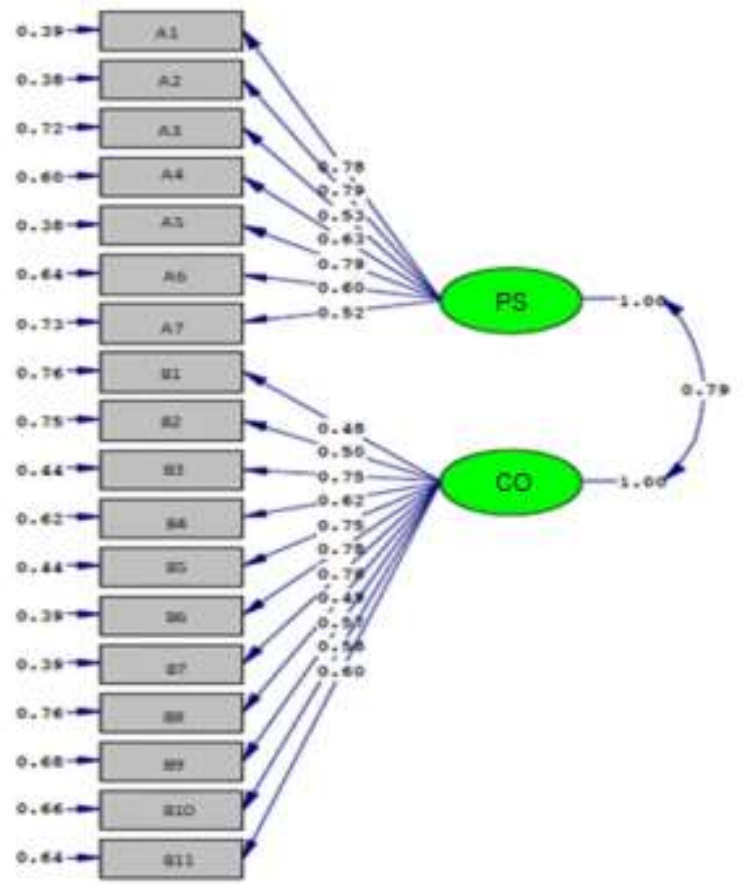

Figure 1. Confirmatory factor analysis model

\section{Findings on Reliability}

An internal consistency coefficient was calculated using the data obtained regarding the reliability. Cronbach's alpha reliability coefficient of the scale was 0.83 for the parental strategies subscale, 0.87 for the child outcomes subscale, and 0.91 for the whole scale, respectively. These coefficients indicate strong internal consistency for the subscales and the total scale (George \& Mallery, 2003).

The Pearson Product Moment Correlation Coefficient was calculated to ensure test retest reliability between the two applications and to identify whether there was any significant relationship between obtained scores. Each correlation was significant at .001 or better: parental strategies subscale $(r=.602)$, child outcomes subscale $(r=.55)$, and total BPSE-R score $(r=.67)$. This shows a moderately significant relation between test-retest scores (Büyüköztürk, 2011).

\section{Discussion, Conclusion, and Recommendations}

This study aimed to adapt the revised version of BPSE-R developed by Holloway and others (2019) to Turkish. The analyses showed that the BPSE-R was an applicable measurement tool that can be used to evaluate the self-efficacy of parents with pre-school children in Turkey. The first stage in the adaptation study was to examine the content of the scale. Once translations and back translations were completed, field experts checked whether each item on the scale was compatible with the target language and culture. After the suggested changes were made, the items in the scale were suitable for determining the self-efficacy level of mothers with children in the preschool age group.

Based on the CFA, which was conducted to determine the construct validity of the BPSE-R, the scale was found to have a two factor structure. This shows that the Turkish version of the scale is compatible with the factor structure of the original scale. These factors were parental strategies and child outcomes. As a result, no item needed to be excluded from the scale, and the factors of the scale and the items included in these factors fully corresponded to the original scale. 
According to CFA results, the fit indices suggested that the two-factor scale including a total of 18 items was an acceptable fit to the sample data $(\mathrm{CFI}=0.96, \mathrm{RMSEA}=0.077, \mathrm{SRMR}=0.059)$. The original scale values determined in the US and Japan samples were CFI $=0.97$, RMSEA $=0.05$ and SRMR $=0.04$ and $\mathrm{CFI}=0.97$, RMSEA $=0.04$ and $\mathrm{SRMR}=0.05$, respectively. According to these findings, it can be stated that two sub-factors of the scale provide information regarding various dimensions of parental self-efficacy and measure the same structure.

As regards the reliability of the BPSE-R, its reliability coefficient over time was measured as 0.67 for the total score. This result is close to the coefficients obtained in the test-retest studies (Holloway et al., 2019) conducted in the US (0.71) and Japan (0.80). In this study, Cronbach's alpha values were calculated as 0.83 in the parental strategies subscale, 0.87 in the child outcomes subscale, and 0.91 for the total scale score.

In Turkey, a limited number of scales evaluate the parenting skills of parents with children in the preschool age group and their self-efficacy for supporting children's development (Elibol, Mağden \& Alpar, 2007; Kılıçarslan, 2007; Kotil, 2010; Seçer, Çeliköz \& Yaşa, 2007). Therefore, the BPSE-R will contribute to the field by helping determine the self-efficacy of parents who have children in the pre-school age group. As shown by validity and reliability analyses, the BPSE-R is adequate for determining parental self-efficacy in terms of psychometric characteristics. Therefore, the BPSE-R may be used in studies conducted with Turkish parents who have children in the preschool age group. Its use in studies concerning various parental efficacy variables would also be beneficial. Furthermore, as the BPSE-R was adapted and used in the US, Japan, and Korea, its adaptation to Turkey might be useful for researchers in terms of making cross-cultural comparisons. The fact that the application of the scale is short and its level of reliability is high will make its use convenient in future research.

Participants in this study were identified through convenience sampling. This may be considered a limitation of the study. Therefore, its replication with a broader population and Turkish parents with various demographic characteristics is recommended. Besides, in this study, the procedures for determining the validity of the BPSE-R were limited to construct and content. Therefore, examining the criterion validity of the BPSE-R may be suggested to obtain additional evidence for validity in further studies.

\section{References}

Bandura, A. (1977). Self-efficacy: toward a unifying theory of behavioral change. Psychological Review, 84(2), 191.

Bandura, A. (1982). Self-efficacy mechanism in human agency. American Psychologist, 37(2), 122.

Bandura, A. (2002). Social cognitive theory in cultural context. Applied Psychology, 51, 269-290. http://dx.doi.org/10.1111/1464-0597.00092.

Bandura, A. (2006). Guide for constructing self-efficacy scales. In F. Pajares \& T. Urdan (Eds.), Selfefficacy beliefs of adolescents (pp. 307-337). Greenwich, CT: Information Age Publishing.

Büyüköztürk, Ş. (2011). Sosyal bilimler için veri analizi el kitabı. [Manual of data analysis for social sciences] (14 $4^{\text {th }}$ ed.). Ankara: Pegem Academy Publishing.

Cavkaytar, A., Aksoy, V., \& Ardıç, A. (2014). Ebeveyn öz yeterlik ölçeği geçerlik ve güvenirlik çalışmasının güncellenmesi. [The updating for study of parental self-efficacy scale validity and reliabilitiy] Anadolu Journal of Educational Sciences International, 4(1), 69.

Coleman, P. K., \& Karraker, K. H. (1998). Self-efficacy and parenting quality: Findings and future applications. Developmental Review, 18(1), 47-85.

Coleman, P. K., \& Karraker, K. H. (2000). Parenting self-efficacy among mothers of school-age children: Conceptualization, measurement, and correlates. Family Relations, 49(1), 13-24.

Coleman, P. K., \& Karraker, K. H. (2003). Maternal self-efficacy beliefs, competence in parenting, and toddlers' behavior and developmental status. Infant Mental Health Journal: Official Publication of the World Association for Infant Mental Health, 24(2), 126-148.

Çelik, H., \& Yılmaz, V. (2013). LISREL 9.1 ile yapısal eşitlik modellemesi [Structural equation modeling with LISREL 9.1]. Ankara: Anı Publishing. 
Çokluk, Ö., Şekercioğlu, G. B., \& Ş. Büyüköztürk. (2012). Sosyal bilimler için çok değişkenli istatistik: SPSS ve LISREL uygulamalart. [Multivariate Statistics for Social Sciences: SPSS and LISREL Applications]. Ankara: Pegem Academy Publishing.

de Montigny, F., \& Lacharité, C. (2005). Perceived parental efficacy: Concept analysis. Journal of Advanced Nursing, 49(4), 387-396.

Demir, S., \& Gündüz, B. (2014). Ebeveyn Yetkinlik Ölçeği'nin uyarlanması: Geçerlik ve güvenirlik çalışmaları. [Adaptation of the parental self-efficacy scale: the study of validity and reliability] Mustafa Kemal Üniversitesi Sosyal Bilimler Enstitüsü Dergisi. [Mustafa Kemal University Graduate School of Social Sciences Journal] 11(25), 309-322.

Elibol, F., Mağden, D., \& Alpar, R. (2007). Anne Babalık Becerilerinde Özyeterlik Ölçeği’nin (1-3 Yaş) Geçerlik ve Güvenirliği. [Validity and reliability of the self-efficacy scale for parenting skills (1-3 years old)] Toplum Hekimliği Bülteni [Bulletin of Community Medicine], 26(3), 2531.

George, D., \& Mallery, P. (2003). SPSS for Windows step by step: A simple guide and reference. (4 ${ }^{\text {th }}$ ed.). Boston: Allyn \& Bacon.

Hambleton, R., \& Patsula, L. (1999). Increasing the validity of adapted tests: Myths to be avoided and guidelines for improving test adaptation practices. Applied Testing Technology Journal, 1(1), 130 .

Hambleton, R. (2005). Issues, designs, and technical guidelines for adapting tests into multiple languages and cultures. In R. Hambleton, P. Merenda, and C. Spielberger (Eds) Adapting Educational and Psychological Tests for Crosscultural Assessment, (pp. 3-38). Mahwah: Erlbaum.

Holloway, S. D. (2010). Women and family in contemporary Japan. Cambridge: Cambridge University Press.

Holloway, S. D., Campbell, E. J., Nagase, A., Kim, S., Suzuki, S., Wang, Q., Iwatate, K., \& Baak, S. Y. (2016). Parenting self-efficacy and parental involvement: Mediators or moderators between socioeconomic status and children's academic competence in Japan and Korea? Research in Human Development, 13(3), 258-272.

Holloway, S. D., Suzuki, S., Kim, S., Nagase, A., Wang, Q., Campbell, E. J., Golshirazi, M., Iwatate, K., \& Nishizaka, S. (2019). Development and cross-national validation of a revised version of the Berkeley Parenting Self-efficacy Scale. Early Childhood Research Quarterly, 47, 309-320.

Holloway, S. D., Suzuki, S., Yamamoto, Y., \& Behrens, K. (2005). Parenting self-efficacy among Japanese mothers. Journal of Comparative Family Studies, 36(1), 61-76.

Jöreskog, K. G., \& Sörbom, D. (1993). LISREL 8: Structural equation modeling with the SIMPLIS command language. Scientific Software International.

Kaya, Ö. (2011). Illköğretim birinci kademe öğrencilerinde ebeveyn katılım algısını açılkamaya yönelik bir model gelişstirme. [Developing a model to explain parental participation perception in primary school students]. (Unpublished Doctoral Dissertation), Gazi University, Ankara, Turkey.

Kılıçaslan, A. (2007). Ebeveynliğe geçiş döneminin çeşitli doğum öncesi ve doğum sonrası etkenler açısından incelenmesi. [Examination of the transition period to parenthood in terms of various prenatal and postnatal factors]. (Unpublished Doctoral Dissertation), Istanbul University, Istanbul, Turkey.

Kline, R. B. (2005). Principles and practice of structural equation modeling: Methodology in the social sciences. New York, NY: The Guilford Press.

Kotil, Ç. (2010). Okul öncesi eğitim kurumuna yeni başlayan 5 yaş çocukların sosyal duygusal uyum düzeylerine annenin ebeveyn öz yeterlik algisl ile okul beklentilerine uyum düzeyinin etkisi. [The effects of mother's parental self-efficacy and adjustment to school expectations on socialemotional adjustment of 5-year-old children who have just started preschool] (Unpublished Master Thesis), Marmara University, Institute of Educational Sciences, Istanbul, Turkey. 
Marsh, H. W., \& Hocevar, D. (1985). Application of confirmatory factor analysis to the study of selfconcept: First-and higher order factor models and their invariance across groups. Psychological Bulletin, 97(3), 562.

MoNE (2013). Milli Ĕgitim Bakanlığı Okul Öncesi Eğitim Programı [Ministry of National Education Preschool Education Program] Ankara: MEB Publications.

Schneewind, K. A. (1995). Impact of family processes on control beliefs. In A. Bandura (Ed.), SelfEfficacy in Changing Societies (pp. 114-148). Cambridge: Cambridge University Press.

Seçer, Z., Çeliköz, N., \& Yaşa, S. (2007). Bazı kişisel özelliklerine göre okul öncesi eğitim kurumuna devam eden çocukların babalarının babalığa yönelik tutumları. [Attitudes towards fatherhood according to some personal characteristics of fathers of children attending pre-school education institution]. Selçuk Üniversitesi Sosyal Bilimler Enstitüsü Dergisi [Selcuk University Graduate School of Social Sciences Journal], 18, 425 - 438.

Senemoğlu, N. (2007). Gelişim öğrenme ve ögretim: Kuramdan uygulamaya [Development, learning and teaching: From theory to practice], Ankara: Gönül Publishing.

Suzuki, S., Holloway, S. D., Yamamoto, Y., \& Mindnich, J. D. (2009). Parenting self-efficacy and social support in Japan and the United States. Journal of Family Issues, 30(11), 1505-1526.

Sümer, N. (2000). Yapısal eşitlik modellemesi. [Structural equation modeling]. Türk Psikoloji Yazıları [Turkish Psychological Articles], 3(6):49-74.

Uyanık Balat, G. (2014). Analyzing self-efficacy and depression levels of mothers who have children in the preschool period. Journal of Human Sciences, 11(2), 661-677.

Uyanık Balat, G., \& Yılmaz, E. (2014). Analyzing child rearing attitudes and parental self-efficacy perception of mothers of preschool children. E-Journal of New World Sciences Academy, 9(4), 394-402.

Uyanık Balat, G. (2015). Analyzing the relationship between self-efficacy perception of mothers and their communication with their preschool children. US-China Education Review, 5(6), 390-399.

Wang, Q. (2019). Mothers' perceptions of stress, parenting self-efficacy, and permissive and inconsistent discipline: insights from China, Japan, and the United States. (Unpublished doctoral thesis). University of California, Berkeley, USA.

Zembat, R., Uyanık Balat, G., Çinko, M., Şengül, L., \& Acar, M. (2008). Anasınıfındaki çocukların ailelerinin özyeterlilik düzeylerinin incelenmesi. [Investigation of self-efficacy levels of families of kindergarten children]. Paper presented at the International Conference of Educational Science, (ICES'08), Kibris. 